\title{
A Rising China in Africa- A Vilfied Comrade? A Perspective From Inside Africa
}

\author{
Elorm Ewurama Kumah* \\ Shanghai University, 99 Shangda Road, Baoshan District.
}

*Corresponding Author: Elorm Ewurama Kumah, Shanghai University, 99 Shangda Road, Baoshan District.

\begin{abstract}
In the past few decades, African leaders have anchored to China in the quest for national and economic development through investment, development financing, aid and trade. Consequently, China weighs profoundly in Africa's future development by offering a compelling alternative partnership, which if appropriately managed can accrue the velocity to accelerate Africa en route for the indispensable growth and development required toalter the living standards of Africans positively. However, China's current approach in Africa has elicited unrelenting scholarly and media attention. The former's dealings with Africa has been tagged by mostly Western media with expressions and terms such as "China's Scramble for Africa", "Patron of African Misgovernment", "The Chinese Model is Failing Africa”, "Neo-colonialism", amongst others. This has been a major tool employed by critiques to mar the image of China internationally, painting China as a ruthless power taking advantage of weaker helpless states in Africa. Nonetheless, and rather ironically, Sino-African relations has been deepening against the odds. China has responded by intensifying its soft power policies towards and in Africa, nevertheless the negative image still lingers. This paper is composed of an analytic diagnosis of China's Soft Power in Africa, emphasising the need to approach criticisms as a means by which Beijing can enhance its attractiveness in Africa while projecting China's African Policy onto the world stage as an emblem of Chinese Foreign policy and the Peaceful Rise of China.
\end{abstract}

Keywords: Sino-African Relations, Soft Power, Alternative Partnership, China's African Policy

\section{INTRODUCTION}

China in the past seven decades has metamorphosed from a poor Asian country into a giant political, economic, social force on the world stage. With a per capita Gross Domestic Product of 188 USD in $1977^{1}$, the country moved away from its originally closed economy to a more open system under the then leader Deng Xiaoping, enlarging relations with other economies such as the United States, neighbouring Asia, as well as Africa. In fact, today, China is the world's largest economy per GDP PPP (Purchasing Power Parity) - a determinant that most scholars agree is the best indicator of a country's economic strength ${ }^{2}$, exceeding the United States since2014 ${ }^{3}$.

From "Journey to the West" (XiyouJi) to "Rush Hour", to house hold names like Gong Li and Zhang $\mathrm{Ziyi}^{5}$, Chinese Culture has reverberated throughout the world in the past decades, and as expected this is not particularly different in the continent of Africa.

It is thus imperative to primarily understand the historical context of Sino-African relations that has evolved from a mixture of solidarity, ideology, politics and trade-oriented with different African

\footnotetext{
${ }^{1}$ http://data.un.org/Data.aspx?q=gdp+china\&d=SNAAMA\&f=grID\%3A101\%3BcurrID\%3AUSD\%3BpcFlag\% 3A1\%3BcrID\%3A156

${ }^{2}$ Graham Allison, "Destined for War, Can China and America Escape Thucydides' Trap?" Houghton Mifflin Harcourt, Boston New York 2017

${ }^{3}$ China Overtakes the US as the World's Largest Economy; Impact on Industries and Consumers Worldwide, EuroMonitor International Report, Retrieved form https://www.iimk.ac.in/libportal/reports/China-OvertakesUS-Worlds-Largest-Economy-White-Paper-Euromonitor-Report.pdf on 16 March 2019

${ }^{4}$ Journey to the West (XiyouJi) - a Chinese novel published in the 16th century during the Ming dynasty and attributed to Wu Cheng'en Rush Hour - a hit movie starring China's renowned Hollywood actor Jackie Chan ${ }^{5}$ Popular Award winning Chinese Actors
} 
countries in the 1950's, to a more strategic economic and diplomatic partnership over the past two decades. The first notable formal Chinese presence in Africa was in the late 1950's after an initial encounter at the Afro-Asian Bandung Conference in 1955. Sino-African relations grew stronger after Bandung and exchange of visits between Chinese and African leaders became more frequent. In order to consolidate the bond, Premier Zhou Enlai made an official tour to Africa from 1963-1964. This tour to date is considered a major milestone that achieved a "lasting effect" in the development of friendly relations between China and Africa ${ }^{6}$.

China has done a tremendous job at working its image, projecting itself as friendly and attractive to the rest of the world. China has already developed a remarkable array of public diplomacy activities over the past decades. Nonetheless, the debate on strategic use of this tool and the professionalization of China's public diplomacy have only just begun ${ }^{7}$.

This paper will discuss how China has attempted to enhance its image in Africa, the various public diplomacy tools employed, the successes of these, as well as how China can employ workable solutions to the pitfalls as a mode restoring the marred image.

\section{China's Place in Global GovernanCe}

The struggle for global dominance by China and the United States may be summed up into the concept of Global Governance, an often used, yet many a time over simplified notion in international relations. As Lawrence S. Finkelstein puts it, there is a great deal of ambiguity, not only in what is meant when we refer to the word global but also what is meant by governance. Many have attempted definitions for Global Governance one of which is by AdilNajam that is the management of global processes in the absence of global government. Others may also define it as the way in which global affairs are managed, typically including a range of actors namely states, regional and international organizations, as well as non-state actors.

In a world where there is no international police, it is often difficult to establish and maintain a system of global governance, not to mention the idea of a "world government", which will not be with tainted with numerous faults and shortcomings. As the People's Republic of China, Xi Jinping, puts it at the first BRI (Belt and Road Initiative) Forum in May 2017, there in fact exists a deficit in world governance. Historically, the international system was plagued with series of wars, where the mighty ruled. Until the establishment of the United Nations and its equivalent institutions, it may have been much harder to maintain world peace. Today, the mighty still rule, but in a more different way than before, the economically powerful "call the shots".

The major reason for the failure of the current global order on many counts is the fact that intergovernmental organizations, specifically the United Nations draw its power and authority from individual states. These states have their individual national interest and it is very much difficult to agree, let alone arrive at a consensus. Therefore, it turns out often to be an affair of competition over national interests rather than the pursuit of the aggregate good. Secondly, it is evident that the mighty will mostly have their way, while the weak will be bullied to accept their fate, being tossed about by the decisions of the powerful nations. Undoubtedly, it is countries like the United States, Britain, France, amongst others that rule the international system. Being among the largest financiers of the United Nations, they often retain special privileges that weaker states like Myanmar and Togo will never enjoy. Thirdly, it is rather extremely difficult to ensure compliance from all states. This makes it difficult to maintain order. While the powerful states go throwing their weight about and doing what they find is in their best national interest, the weaker states may also express indifference in complying with the international status as is observed in the case of North Korea and nuclear proliferation.

Against this background, indeed, there is a general consensus in the literature that the world would have been worse in the absence of some form of global governance as we have it today. For instance, there have been near World Wars like the Cuban Missile Crisis of October 1962. However, these did not lead the world into utter turmoil like it would have in the absence of the current international

\footnotetext{
${ }^{6}$ Hagan Sibiri, "Why China? The Perspective from Inside Africa", The African Policy Journal, Harvard Kennedy School Student Publication, October 32018 retrieved from http://apj.hkspublications.org/why-china/ ${ }^{7}$ Ingrid d'Hooghe "The Rise of China's Public Diplomacy", Netherlands Institute Of International Relations Clingendael, July 2007
} 
governance arrangement. Not all countries will be utterly satisfied with the current system of global governance, but certainly none will have it thrown away because there continues to be a need for it. As such, it will be unwise to absolutely condemn the system. What will be expedient is to consider some thorough adjustment to the current international order with the goal of rendering it more efficient and effective. It will be necessary to ensure that power does not rest in the hands of a single country, be it the United States or China.

China may have also well enough started "throwing its weight about", taking advantage of the loopholes in the international system. "China enjoys such superiority in its balance of economic power that many other states have no realistic option but to comply with its wishes, even when the international system is on their side. In 2016, for instance, China flatly rejected an unfavourable ruling by the Permanent Court of Arbitration over a dispute with the Philippines in the South China Sea, setting the table for another contest of wills. In this standoff, and others involving the South China Sea, China has demonstrated an ability to combine charm, largesse, bribes, and blackmail to find "compromises" that give it most of what it wants."

Ultimately, the future of Global Governance should look towards greater representation of weaker states in central decision making. For instance, Least Developed Countries (LDCs) are more adversely affected by climate change but often have the least say in climate diplomacy. The United Nations Security Council, for instance, has been vehemently criticized for misrepresentation of the global reality However,. China is gradually bridging the gap. Also, China is currently a member of the United Nations Security Council. The position of China and other emerging economies will lead to a fairly equitable representation of both the powerful and the weak in order to bring some form of balance into the system. Some may therefore see China's rise as a desirable ingredient for a more sustainable world governance.

Furthermore, more regional and multilateral cooperation is recommended to depolarize the system. Strengthening organizations such as BRICS (Brazil, Russia, India, China, South Africa) and regional bodies such as ASEAN (Association of South East Asian Nations), ECOWAS (Economic Community of West African States) among others will help in disintegrating monopoly of powerful states in the international system. This will happen where the multilateral bodies exercise their cooperative power as checks and balances to the "big guys". For instance, the voice of Brazil against the United States may not carry as much authority as the voice BRICS against the United States. Finally, more countries should be willing to compromise on some national interests for the greater good particularly the major powers. Where there is no compromise of the interests among different nations, the result can only be a weak system which can only remain a caricature of the desired world governance. Countries like China are setting the pace in this regard by taking responsibility for instance of its immense pollution of the environment. Today, China is the largest investor in renewable energy and keeps planting tons of trees to deflect some of the harmful greenhouse gases emitted into the atmosphere mostly through its rapid industrialization in the past few decades. Indeed, only a collective effort and sense of responsibility can make Global Governance work.

\section{What CONSTITUTES CHINESE SOFT POWER IN AFRICA?}

\subsection{Soft Power is the New Power}

Also been called various names like public diplomacy (gonggongwaijiao) and 'soft power' (ruanshili) in official speeches and documents illustrates a growing awareness among China's policy-makers of the possibilities of these tools. 'We should conduct public diplomacy in a more effective way', said Chinese Premier Wen Jiabao in a 2007 article in China's national newspaper, The People's Daily, as well as the website of the Chinese Embassy in the United Stated, amongst other platforms " titled:"Soft Power: A New Focus at China's 'Two Sessions" with the "two sessions" referring to the 2007 annual sessions of China's National People's Congress and China's People's Consultative Conference. In academic circles, the concepts of public diplomacy and soft power are increasingly being debated ${ }^{9}$.

\subsection{Definition}

Though the concept itself may not be new, the term Soft Power permeated international relations from the work of Joseph Nye - a renowned American political scientist. In his book "Bound to lead: The

\footnotetext{
${ }^{8}$ Soft power, a new focus at China's "two sessions"(03/14/07), Retrieved from http://www.chinaembassy.org/eng//xnyfgk/t303537.htm

9Ingrid d'Hooghe“The Rise of China's Public Diplomacy", Netherlands Institute Of International Relations Clingendael, July 2007
} 
changing nature of American Power" published in 1990, Nye coined the expression Soft Power. Soft Power has since been highly employed by scholars and policy makers alike in conversations around interstate relations and great power politics. The concept of 'soft power' is understood as defined by Joseph Nye: 'the influence and attractiveness a nation acquires when others are drawn to its culture and ideas' ${ }^{10}$.

China has evidently employed traditional methods of enhancing soft power that are not peculiar to the country alone. Other powers such as the United States, United Kingdom, etc. have used these tools to inspire admiration and attraction too. Being a winner is always appealing and China's rise offers many economic opportunities for international business. Furthermore, in Africa China's approach to international relations and economic and social development is being followed with great interest and approval. The attraction is further enhanced by a number of factors:

\section{a. More Appealing Than the West.}

China has no colonial past; in some cases there is a close relationship going back to solidarity with national liberation movements; and close ties with China serve as a counterbalance to Western, in particular, American hegemony. In addition, African leaders feel treated as equals by the Chinese and serve as a source of inspiration as a "former poor country", and a fellow developing country. China is investing in areas that are important to Africa's future but are often avoided by Western aid and investment, such as infrastructure.

\section{b. Scholarships}

Inviting foreign students to China has become another powerful diplomatic instrument. The statistics of foreign student enrolment in China provide another illustration of the international attraction to China's language and culture. In 2005 more than 141,000 foreigners studied in China. Today, China has overtaken the US and UK as the top destination for Anglophone African students. The surge in the number of African students in China is remarkable. In less than 15 years the African student body has grown 26-fold - from just under 2,000 in 2003 to almost 50,000 in 2015. According to the UNESCO Institute for Statistics, the US and UK host around 40,000 African students a year. China surpassed this number in 2014, making it the second most popular destination for African students studying abroad, after France which hosts just over 95,000 students ${ }^{11}$. Most come to learn the language with the future aim of doing business with China, but an increasing number are studying Chinese arts, philosophy, history and traditional Chinese medicine ${ }^{12}$. This is evidential enough that China is quickly becoming a country of choice even for the younger African generation; which is a promise of upscaled prospective future relationship.

\section{c. Economic Aid}

The most important domestic factor that has shaped and still shapes China's foreign policy and diplomacy is the country's economic rise. China's opening up policy and its integration into the world economy and the resulting spectacular growth have made China an economic power house. It is this economic success that has opened many doors in the world and has given Beijing the leverage and confidence to assert itself as a global player. But at the same time this economic rise is perceived as a threat by many countries. Companies are sometimes simply told to invest in specific projects in a given country; in other cases they are encouraged by soft loans and government subsidies ${ }^{13}$. Coupled with low labour costs and China's growing technological know-how, which they are often willing to share, Chinese companies are attractive business partners in Africa. The total amount that China spends on development aid in 2007 is estimated to be US\$2.7 billion ${ }^{14}$. In Africa alone China currently had spent more than one billion dollars and President $\mathrm{Hu}$ had pledged to double aid to Africa

\footnotetext{
${ }^{10}$ Joseph S. Nye, Soft Power: The Means to Success in World Politics (Cambridge MA: Perseus Publishing, 2004).

${ }^{11}$ Victoria Breeze; Nathan Moore, "China has overtaken the US and UK as the top destination for Anglophone African students”Michigan State University, June 30, 2017 retrieved from https://qz.com/africa/1017926/chinahas-overtaken-the-us-and-uk-as-the-top-destination-for-anglophone-african-students/

${ }^{12}$ Ingrid d'Hooghe“"The Rise of China's Public Diplomacy", Netherlands Institute Of International Relations Clingendael, July 2007

${ }^{13}$ Ibid

${ }^{14}$ Ibid
} 
by 2009, from its 2006 level, to US\$ 3 billion in loans, US\$ 2 billion in export credits and a US\$ 5 billion fund to encourage Chinese investment in Africa. China also organizes extensive training programmes for professionals from developing countries, builds schools and hospitals, and sends experts and youth volunteers to developing countries. This all adds to a positive impression.

\section{d. Media}

Like BBC is to the United Kingdom and CNN is to the United States, CGTN is to China. Until recently, China's domestic media were the main instruments for informing the outside world about China. There have been English-language Chinese newspapers and journals targeting foreign audiences since the early years of the People's Republic of China. China Radio International broadcasts in all of the major world languages. The official Chinese news agency, Xinhua, has an English-language service, and China Global Television Network (CGTN) has expanded its international broadcasting for satellite television subscribers. CGTN also hired foreign anchors and editors to enable it to cater better for foreign viewers. Now in Africa, CGTN Africa has been a useful tool to tell the story of China and Africa unlike the critiques will tell it $^{15}$. Not only does this present the other side of the story but also is appealing to Africa in terms of jobs created in the resident cities - killing two birds with a stone.

\section{e. A Beacon to "Fellow" Developing Countries}

China is rising economically and has become more and more confident that in a fashion that cannot be ignored in world politics, partly playing a role as a friend of the voiceless nations in international organisations and also rubbing shoulders with the big powers. Economic power has quickly translated to political power in international stage. China's pragmatic model shows that you can have economic development without far-reaching political reform. Internationally, the model is based on the principles of non-interference in domestic affairs and 'no-political-strings attached' foreign aid and trade. China is becoming an example for other nations around the world that are trying to figure out how to develop their countries and fit into the international order in a way that allows them to be independent and to protect their political choices. Countries in Africa, which are fed up with Western criticism, are looking at the Chinese model and rethinking their own development paths. In his address at the $73^{\text {rd }}$ United Nations General Assembly, The President of Ghana, Nana Addo Danquah Akuffo Addo addressed the subject by professing Ghana's inclination for dealing with China, alleviating the concerns of the member states on the possible "recolonization" of Africa by China ${ }^{16}$. Coupled with Beijing's expanding aid policies, China's image in developing countries is mostly positive.

\section{Towards a Welcomed PARTNershiP- AdDRESSING THE CRITICISMS}

Despite all the aforementioned, China's economic rise and subsequent immersion in Africastirssome nervousness in governments and business circles in the world. They worry about losing industries and jobs to China and about their growing trade deficits with China. In the United States the 'China Threat' debate flares up regularly, sometimes leading to congressional moves to introduce legislation that will punish China if it does not comply with US requests to change a specific policy. African countries - individuals and governments alike, have concerns too. Paying a closer attention to alleviating those worries will serve the interests of both parties better and enhance China's Soft Power.

Firstly, China should insist on Transparency in the terms and conditions of Contracts between Chinese Government and African leaders. The fears expressed by the people of Africa on the presence of China in Africa will be alleviated if contracts and economic deals between Beijing and African leaders are made accessible to the increasingly politically active population of Africans. China should insist from their side of the bargain that details of economic agreements are not withheld from the public so as to do away with all forms of speculations that lead to misguided allegations and litigation of wrongfully crafted stories. This will project China as a party which is responsible and interested in African well-being and not only in the resources of the continent as the west portrays them.

\footnotetext{
${ }^{15}$ Pengfei, Zhang, "About CCTV Africa". CNTV. (2012-11-01).

http://english.cntv.cn/program/africalive/20120111/117620.shtmlRetrieved 22 Mar. 19

${ }^{16}$ Statement By The President Of The Republic Of Ghana, H.E. Nana AddoDankwaAkufo-Addo At The 73rd

Session Of The United Nations General Assembly On Wednesday, 26M September, 2018 New York
} 
Moreover, China should focus on creating an industrialized Africa rather than on infrastructural development. One of the major criticisms against China is the fact that it is only in Africa to squander its vast resources and leave the continent in utter debt. Critiques echo that China's investments in Africa are mostly with the end goal of taking more from the continent that it gives. China can focus on increasing its investments in industries, such as the recent establishment of China's Fujian Sentuo Steel in Ghana ${ }^{17}$. This projects China as a power preoccupied with assisting Africa to stand on its own feet independently rather than making it a beautiful continent inherently dependent on China for commodities as basic as a toothpick ${ }^{18}$.

There is a need for increased consciousness amongst non-state actors, like the citizens, as major contributors to China's image and thus soft power in Africa and beyond. With the influx of African students, workers, business personnel, diplomats etc. in China and vice versa, China's image as already established does not depend on national policies only but largely on the interpersonal relations of citizens to citizens. Social media platforms in Africa are constantly flooded with condemnation of Chinese citizens' behaviour in Africa ranging from racism, blatant disregard for laws in their host countries, just to mention a few. As expressed by one Lu Xinsheng in an interview on the unlawful smuggling and selling of counterfeit goods in Tanzania, "Our bad habits have followed us". Chinese businessmen smuggle ivory and rhino horns out of Tanzania and flood local markets with imitation goods while contractors constantly attempt to undercut each other, resulting in shoddy infrastructure projects $^{19}$. Indeed, only a few bad nuts can make so much damage. The general citizenry must be sensitized to recognize that they are 'non-state' actors who play an increasingly significant role in diplomacy and Chinese soft power.

Finally, Chinese companies should make use of locals rather than importing labour from China. Another bitter complaint of Chinese aid has been that though there are no strings attached unlike with the West, and no expensive consultancy fees, Chinese workers are imported into African countries to work on projects with the reason that they do not shy away from difficult construction projects in remote areas. With the alarming rate of youth unemployment in many parts of Africa, it is often alarming to see a neglect of the dormant manual labour for a literal import of expertise that can otherwise be obtained locally. Chinese investors can consider this as an opportunity for technology transfer and training.

\section{CONCLUSION}

Sino-African relations is experiencing quantum growth and is unlikely to see any immediate retrogression. Amidst the burning denunciations and reproaches, China should take advantage of the myriad criticisms and scholarly articles that has constantly bombarded Beijing as a compass towards enhancing its power. China should listen to the accusers.

Africa's might have found true alliance with China and are willing to sustain the co-operation for as long as necessary. The onus then lies on China to play a fair game to keep her side of the bargain. A true "comrade" after all must be willing to listen to the concerns of his friends if he indeed cares about their relationship.

\section{REFERENCES}

[1] Breeze, Victoria; Moore, Nathan, "China has overtaken the US and UK as the top destination for Anglophone African students" Michigan State University, June 30, 2017 retrieved from https://qz.com/ africa/1017926/china-has-overtaken-the-us-and-uk-as-the-top-destination-for-anglophone-african-students/

[2] China-Africa relations hurt by bad Chinese behaviour, says ambassador retrieved from https://www. Theguardian.com/world/2014/jul/17/chinese-ambassador-tanzania-china-africa-relationship-ivory-smuggl ing-counterfeit on 22 Mar. 19

\footnotetext{
${ }^{17}$ Chinese firm commissions 80-mln-USD ceramic tiles factory in Ghana Retrieved from https://africa.cgtn.com/2019/02/28/chinese-firm-commissions-80-mln-usd-ceramic-tiles-factory-in-ghana/ on 22 Mar. 19

${ }^{18}$ Ghana Imports Tooth-Picks Worth Ghc18 Million From China - AGI Reveals retrieved from https://allafrica.com/stories/201805150888.html on 22 Mar. 19

${ }^{19}$ China-Africa relations hurt by bad Chinese behaviour, says ambassador retrieved from https://www.theguardian.com/world/2014/jul/17/chinese-ambassador-tanzania-china-africa-relationship-ivorysmuggling-counterfeit on 22 Mar. 19
} 
[3] Chinese firm commissions 80-mln-USD ceramic tiles factory in Ghana Retrieved from https://Africa.cgtn. com/2019/02/28/chinese-firm-commissions-80-mln-usd-ceramic-tiles-factory-in-ghana/ on 22 Mar. 19

[4] Cho, Young Nam, and Jong HoJeong. "China's Soft Power: Discussions, Resources, and Prospects." Asian Survey 48, no. 3 (2008): 453-72. doi:10.1525/as.2008.48.3.453.

[5] Ingrid d'Hooghe "The Rise of China's Public Diplomacy", Netherlands Institute Of International Relations Clingendael, July 2007

[6] Erickson, Andrew S., and Austin M. Strange. "CHINA'S BLUE SOFT POWER: Antipiracy, Engagement, and Image Enhancement." Naval War College Review 68, no. 1 (2015): 71-92. http://www.jstor.org/ stable/26397817.

[7] Ghana Imports Tooth-Picks Worth Ghc18 Million From China - AGI Reveals retrieved from https://allafrica.com/stories/201805150888.html on 22 Mar. 19

[8] Garrison, Jean A. "Turning on the Charm." The Review of Politics 70, no. 2 (2008): 334-36. http://www.jstor.org/stable/20453007.

[9] Keane, Michael. "Keeping Up with the Neighbors: China's Soft Power Ambitions." Cinema Journal 49, no. 3 (2010): 130-35. http://www.jstor.org/stable/40800745.

[10] Paradise, James F. "China and International Harmony: The Role of Confucius Institutes in Bolstering Beijing's Soft Power." Asian Survey 49, no. 4 (2009): 647-69. doi:10.1525/as.2009.49.4.647.

[11] Sautman, Barry, and Yan Hairong. "The Forest for the Trees: Trade, Investment and the China-in-Africa Discourse." Pacific Affairs 81, no. 1 (2008): 9-29. http://www.jstor.org/stable/40377480.

[12] Sibiri Hagan, "Why China? The Perspective from Inside Africa”, The African Policy Journal, Harvard Kennedy School Student Publication, October 32018 retrieved from http://apj.hkspublications.org/whychina/

[13] Wang, Yiwei. "Public Diplomacy and the Rise of Chinese Soft Power." The Annals of the American Academy of Political and Social Science 616 (2008): 257-73. http://www.jstor.org/stable/25098003.

[14] Nye, Joseph S. "Bound to lead: The changing nature of American power." New York: Basic Books

[15] Joseph S. Nye, Soft Power: The Means to Success in World Politics (Cambridge MA: Perseus

[16] Publishing, 2004).

[17] Nye, Joseph S. "Soft Power." Foreign Policy, no. 80 (1990): 153-71. doi:10.2307/1148580.

[18] Nye, Joseph S. "Public Diplomacy and Soft Power." The Annals of the American Academy of Political and Social Science 616 (2008): 94-109. http://www.jstor.org/stable/25097996.

[19] William A. Callahan. "China's Strategic Futures." Asian Survey 52, no. 4 (2012): 617-42. doi:10.1525/as.2012.52.4.617.

[20] Zhang, Pengfei, "About CCTV Africa". CNTV. (2012-11-01). http://english.cntv.Cn/program/africalive/2 0120111/117620.shtml Retrieved 22 Mar. 19

Citation: Elorm Ewurama Kumah. "A Rising China in Africa-A Vilfied Comrade? A Perspective From Inside Africa” International Journal of Political Science (IJPS), vol 6, no.1, 2020, pp. 33-39. doi: http://dx.doi.org/10. 20431/2454-9452.0601004.

Copyright: (C) 2020 Authors. This is an open-access article distributed under the terms of the Creative Commons Attribution License, which permits unrestricted use, distribution, and reproduction in any medium, provided the original author and source are credited. 